\title{
Comparative Studies on Top Working Techniques for Bud Wood Production in Apple (Malus $\times$ Domestica Borkh.)
}

\author{
Ankita Dhiman, D. D. Sharma*, D. P. Sharma and Gopal Singh \\ Department of Fruit Science, Dr. YS Parmar University of Horticulture and Forestry \\ Nauni, Solan Himachal Pradesh, (India) \\ *Corresponding author
}

Keywords

Apple, Top

working, Bud

wood, Graftable

scion wood,

Graftable shoots

Article Info

Accepted:

04 October 2020

Available Online:

10 November 2020

\section{A B S T R A C T}

\begin{abstract}
The present investigation entitled "Comparative studies on top working techniques for bud wood production in apple (Malus $x$ domestica Borkh.)" was carried out in the Department of Fruit Science, Dr. YS Parmar University of Horticulture and Forestry, Nauni, Solan (H.P.) India in 2019-2020. The experiment was laid out in Randomized Block Design consisting of eleven treatments replicated thrice. In this experiment, three grafting methods viz., tongue, cleft and bark performed at $1 \mathrm{~m}, 1.25 \mathrm{~m}$ and $1.5 \mathrm{~m}$ height in combination with two budding methods viz., T-budding and chip budding done at $1 \mathrm{~m}$ height were used for top working. The results revealed that the highest graft take success $(93.27 \%)$, total number of shoots (49.67), number of secondary shoots (30.67), annual primary shoot extension growth $(182.00 \mathrm{~cm})$, annual secondary shoot extension growth $(112.00 \mathrm{~cm})$, average annual shoot extension growth $(147.00 \mathrm{~cm})$, number of buds (57.80), number of leaves (59.59), total chlorophyll content $(2.89 \mathrm{mg} / 100 \mathrm{~g})$, diameter of graftable shoots ( 7.75 $\mathrm{mm}$ ), number of graftable shoots (248.00) and per cent graftable scion wood (52.73\%) were recorded in the plants top worked with tongue grafting at $1.25 \mathrm{~m}$ height. Whereas, diameter of shoots $(>8 \mathrm{~mm})$ i.e. $17.35 \mathrm{~mm}$ and number of shoots $(>8 \mathrm{~mm})$ i.e. 164.00 were found to be highest in the plants top worked with cleft grafting at a height of $1 \mathrm{~m}$. Therefore, tongue grafting at a height of $1.25 \mathrm{~m}$ resulted in maximum bud wood production for top working in apple.
\end{abstract}

\section{Introduction}

The cultivated apple (Malus $\times$ domestica Borkh.) which is a member of family Rosaceae and sub family Maloidae is native to South West Asia. In India, it was introduced in the middle of nineteenth century, yet it has attained the status of being most important temperate fruit with higher economic returns (Singh et al., 2016). In
India, the commercial cultivation of apple is largely confined to the states of Jammu \& Kashmir, Himachal Pradesh and Uttarakhand which together account for 99 per cent of the total production (Chadha and Awasthi, 2005). However, its cultivation has been extended to the states of Arunachal Pradesh, Sikkim, Nagaland, Meghalaya and Nilgiri hills of Tamil Nadu, where favourable climatic conditions prevail (Singh and Sharma, 2017). 
In India, it is cultivated in an area of about 3 , 10,000 ha with a production of 24, 20,000 MT (Anonymous, 2018a). Apple holds a significant position in horticultural wealth of Himachal Pradesh and thus, the state is also regarded as "Apple Bowl" of India. It is the second largest producer of apple in India after Jammu and Kashmir (Chadda, 2001). It is widely grown in high-hills of Shimla, Kullu, Kinnaur, Sirmour, Lahaul Spiti and Mandi districts and is cultivated in an area of $1,13,154$ ha with a production of $3,68,603 \mathrm{MT}$ (Anonymous, 2018b). Apple cultivars belonging to Delicious group constitutes around 90 per cent of the varieties grown in Himachal Pradesh (Jindal et al., 1992). Traditionally used methods for the vegetative propagation of apple in Himachal Pradesh are tongue grafting and T-budding methods, but a number of other methods have also been tried and found promising for propagation of apple. For example, chip budding method has become popular among the nurserymen in Europe and USA for propagating a wide range of fruits because of its superiority over conventional propagation methods (Howard et al., 1974). Mukred and Hrotko (1989) in Hungary reported best results through chip budding in case of apple. They observed more upright scion growth and a better bud take success in chip budding than T-budding method. For top working of apple, various methods namely tongue, cleft, bark grafting, chip and T- budding can be used. Cleft and bark grafting are the most widely used techniques (Hartmann et al., 1997). These two methods are performed when sap starts flowing in spring. Nowadays, a large number of newly improved cultivars of apple are being imported from other countries. These cultivars are gaining popularity with the growers because of their good fruit quality, regular bearing habit and lower chilling requirements. Thus, there is a great demand for these cultivars among farmers. Also, the ultimate success of apple orcharding largely depends on the good quality planting material. Therefore, for successful apple cultivation, it is important to procure scions wood from the plants which have been correctly identified and to multiply them on mass scale so that it can be made easily available to each and every common orchardist. Therefore, the present studies were conducted to investigate the effect of top working techniques on bud wood production of apple.

\section{Materials and Methods}

The present investigation entitled "Comparative studies on top working techniques for bud wood production in apple (Malus $x$ domestica Borkh.)" was carried out in the Department of Fruit Science, Dr. YS Parmar University of Horticulture and Forestry, Nauni, Solan (H.P.) India in the year 2019-2020. The experimental apple orchard was situated in $30^{\circ} 51^{\prime}$ North latitude and $76^{\circ}$

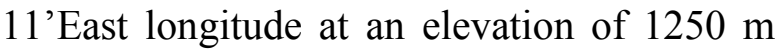
above mean sea level and agro-climatically the experimental orchard comes under zone II of Himachal Pradesh which is sub-temperate, sub-humid mid-hill region. In this zone, the summers are moderately hot during May-June and the winters are quite severe during December-January. Annual precipitation is in the range of $110-120 \mathrm{~cm}$, the maximum amount of which is received as monsoon rains during June to September.

The experiment was laid out in Randomized Block Design consisting of eleven treatments replicated thrice. In this experiment, three grafting methods viz., tongue, cleft and bark performed at $1 \mathrm{~m}, 1.25 \mathrm{~m}$ and $1.5 \mathrm{~m}$ height in combination with two budding methods viz., T-budding and chip budding done at $1 \mathrm{~m}$ height were used for top working. Jeromine was used as a scion cultivar which was top worked on Vance Delicious plants. Plants selected under the present study were healthy and uniform in size. Scion sticks used for 
grafting were taken from previous year's growth collected from healthy and bearing trees. Scion wood for budding was collected from the current season's growth at the time of budding. Twenty five years old experimental trees were dehorned at different heights viz., $1 \mathrm{~m}, 1.25 \mathrm{~m}$ and $1.5 \mathrm{~m}$ during the month of March. There were three grafting methods which were performed in the month of March, 2019 and two budding methods performed in August, 2019. In total, eleven number of treatment combinations were made and each treatment was replicated thrice. The complete details of the experiment in the present studies was as follows:

$\mathrm{T}_{1}=$ Tongue grafting at $1 \mathrm{~m}$ height

$\mathrm{T}_{2}=$ Tongue grafting at $1.25 \mathrm{~m}$ height

$\mathrm{T}_{3}=$ Tongue grafting at $1.5 \mathrm{~m}$ height

$\mathrm{T}_{4}=$ Cleft grafting at $1 \mathrm{~m}$ height

$\mathrm{T}_{5}=$ Cleft grafting at $1.25 \mathrm{~m}$ height

$\mathrm{T}_{6}=$ Cleft grafting at $1.5 \mathrm{~m}$ height

$\mathrm{T}_{7}=$ Bark grafting at $1 \mathrm{~m}$ height

$\mathrm{T}_{8}=$ Bark grafting at $1.25 \mathrm{~m}$ height

$\mathrm{T}_{9}=$ Bark grafting at $1.5 \mathrm{~m}$ height

$\mathrm{T}_{10}=\mathrm{T}$-budding at $1 \mathrm{~m}$ height

$\mathrm{T}_{11}=$ Chip budding at $1 \mathrm{~m}$ height

All the cultural practices viz., de-suckering, staking, cutting of the polythene strips, irrigation, basin preparations, weeding etc., were done uniformly in the selected experimental apple orchard.

The data on Graft/bud-take success (\%), total number of shoots, number of secondary shoots, annual primary shoot extension growth $(\mathrm{cm})$, annual secondary shoot extension growth $(\mathrm{cm})$, average annual shoot extension growth $(\mathrm{cm})$, number of buds, number of internodes, total number of leaves, average leaf area $\left(\mathrm{cm}^{2}\right)$, total chlorophyll content $(\mathrm{mg} / \mathrm{g}$ fresh weight), diameter of grafted branches $(\mathrm{mm})$, proportion of shoots, graftable scion wood (\%) were recorded. graft/bud-take success (\%) was calculated by method given by Rafikul (2013) and Total chlorophyll content was estimated with DMSO (Dimethyl Sulphoxide) method as suggested by Hiscox and Israeistam (1979).

The data recorded from the experiments was calculated, analysed and subjected to statistical analysis, wherever required, using the standard methods as described by Gomez and Gomez (1984). Five per cent level of significance was used to test different variables.

\section{Results and Discussion}

It is evident from the data presented in Table 1 that different top working techniques had a significant effect on graft/bud take success and vegetative growth parameters of apple. The maximum graft/bud take success (93.27 $\%$ ) was recorded in treatment tongue grafting at $1.25 \mathrm{~m}$ height $\left(\mathrm{T}_{2}\right)$, which was statically superior than all other treatments. While, the minimum graft/bud take success $(69.37 \%)$ was found in bark grafting at $1.5 \mathrm{~m}$ height $\left(\mathrm{T}_{9}\right)$, which was found to be statistically at par with cleft grafting $(75.48 \%)$ at $1.25 \mathrm{~m}$ height $\left(\mathrm{T}_{5}\right)$. The maximum success obtained through tongue grafting at a height of $1.25 \mathrm{~m}$ was due to the reason that tongue grafting was performed on secondary shoots. The shoots used for top working were almost pencil thickness. Thus, there was complete interlocking between scion and stock resulting in cambium matching and better graft take success. These results are in accordance with the findings of Gautam and Banyal (2003) who reported maximum success in top working of walnut when tongue grafting was done on one-year old forced shoots. Dwivedi et al., (2000) also recorded maximum graft success through tongue grafting method in apricot. They reported superiority of tongue grafting over other methods, which might be because of favourable temperature and relative humidity prevailing during the period 
following grafting and rapid flow of sap in stock and scion which might have favoured the healing process and established the continuity of cambial and vascular tissues for better graft take. Similar findings were also reported by Bhardwaj (1983), Mehta et al., (2018), Sharma and Dhillon (1981) and Srivastava et al., (2007). It was also observed that grafting success depends on proper alignment of parenchymatous tissues of both scion and stock and the skills of grafters (Mng'omba et al., 2010). Adequate aeration and auxins play an important role in callus formation and grafting success as reported by (Rongting and Pinghai, 1993; Vahdati, 2000; Hartmann et al., 2007 and Rezaee and Vahdati, 2008).

The highest total number of shoots per tree (49.67) were obtained in the treatment tongue grafting at $1.25 \mathrm{~m}$ height $\left(\mathrm{T}_{2}\right)$, which was significantly superior than all other treatments. Minimum total number of shoots per tree (13.33) were recorded in treatment budding at $1 \mathrm{~m}$ height $\left(\mathrm{T}_{10}\right)$, which was statistically at par with chip budding (16.00) at $1 \mathrm{~m}$ height $\left(\mathrm{T}_{11}\right)$. Maximum number of shoots in tongue grafting might be due to complete interlocking between scion and stock that resulted in more nutrient uptake and better growth. The differences in shoot formation in relation to various grafting techniques might be due to the nutritional factors like the quantity of carbohydrates in the plant (Tchoundjeu et al., 2010). The lowest shoot formation with the budding techniques could be attributed to the low carbohydrate reserves as reported by Akinnifesi et al., 2008 and Tchoundjeu et al., 2010).These results are also in accordance with the findings of Gill and Sharma (1996) who reported that tongue grafting produced more sprouts and a greater number of shoots in peach. Similar results were also reported by Plathia et al., (2016) and Sharma et al., (2018) in peach and Chandel et al., (1998) in kiwifruit.
Tongue grafting at $1.25 \mathrm{~m}$ height $\left(\mathrm{T}_{2}\right)$ showed significantly highest number of secondary shoots (30.67), which was higher than all other treatments. However, no secondary shoots were emerged in the plants top worked with T-budding at $1 \mathrm{~m}$ height $\left(\mathrm{T}_{10}\right)$ and chip budding at $1 \mathrm{~m}$ height $\left(\mathrm{T}_{11}\right)$. These results are in conformity with Sharma and Singh (1979) who also reported greater number of secondary shoots with tongue grafting in peach. Similarly, maximum number of secondary shoots have also been reported by Zarad and Saleh (1994) in avocado, Kumar and Ananda (1996) in apple and Chauhan et $a l .$, (2000) in apricot.

The highest annual primary shoot extension growth $(182.00 \mathrm{~cm})$ was recorded in the treatment tongue grafting at $1.25 \mathrm{~m}$ height $\left(\mathrm{T}_{2}\right)$, which was statistically at par with treatment bark grafting $(177.28 \mathrm{~cm})$ at $1.25 \mathrm{~m}$ height $\left(\mathrm{T}_{8}\right)$. While, the lowest annual primary shoot extension growth $(22.46 \mathrm{~cm})$ was observed with T-budding at $1 \mathrm{~m}$ height $\left(\mathrm{T}_{10}\right)$, which was statistically at par with chip budding $(26.01 \mathrm{~cm})$ at $1 \mathrm{~m}$ height $\left(\mathrm{T}_{11}\right)$. These results are in conformity with the findings of Zenginbal et al., (2006) who reported that higher shoot growth in tongue grafted plants may be attributed to early union formation, early sprouting and maximum shoot length. Similar results were also reported by Chauhan et al., (2000); Bohra and Singh (2008). Karldag and Estken (2012) also observed that shoot length decreased significantly by increasing the grafting height.

Tongue grafting at $1.25 \mathrm{~m}\left(\mathrm{~T}_{2}\right)$ gave highest $(112.00 \mathrm{~cm})$ annual secondary shoot extension growth, which was statistically at par with bark grafting $(109.27 \mathrm{~cm})$ at $1.25 \mathrm{~m}$ height $\left(\mathrm{T}_{8}\right)$. However, no secondary shoots emerged in the plants top worked with $\mathrm{T}$ budding at $1 \mathrm{~m}$ height $\left(\mathrm{T}_{10}\right)$ and chip budding at a height of $1 \mathrm{~m}\left(\mathrm{~T}_{11}\right)$. Daouda et al., (2018) reported that top grafting doubles the number 
of lateral branches than budding in cocoa. Similar findings were also reported by Akinnifesi et al., (2008) and Tchoundjeu et al., (2010).

Tongue grafting at $1.25 \mathrm{~m}$ height $\left(\mathrm{T}_{2}\right)$ resulted in maximum number of buds (57.80), which were statistically at par with tongue grafting at $1 \mathrm{~m}$ height $\left(\mathrm{T}_{1}\right)$, cleft grafting at $1 \mathrm{~m}$ height $\left(\mathrm{T}_{4}\right)$, bark grafting at $1 \mathrm{~m}$ height $\left(\mathrm{T}_{7}\right)$ and bark grafting at $1.25 \mathrm{~m}$ height $\left(\mathrm{T}_{8}\right)$ with average number of buds of 56.70, 54.71, 54.64 and 57.40, respectively. However, T-budding done at a height of $1 \mathrm{~m}\left(\mathrm{~T}_{10}\right)$ gave minimum (11.06) number of buds, which was at par with chip budding (12.56) at $1 \mathrm{~m}$ height $\left(\mathrm{T}_{11}\right)$.

Maximum number of internodes (56.80) were recorded in the trees top worked with tongue grafting at $1.25 \mathrm{~m}$ height $\left(\mathrm{T}_{2}\right)$ and was statistically at par with tongue grafting at $1 \mathrm{~m}$ height $\left(\mathrm{T}_{1}\right)$, cleft grafting at $1 \mathrm{~m}$ height $\left(\mathrm{T}_{4}\right)$ and bark grafting at $1.25 \mathrm{~m}$ height $\left(\mathrm{T}_{8}\right)$ with average number of internodes i.e. 55.22, 53.25 and 52.85, respectively. Whereas, Tbudding done at a height of $1 \mathrm{~m}\left(\mathrm{~T}_{10}\right)$ gave minimum number of internodes (10.06) and were at par with chip budding (11.56) at $1 \mathrm{~m}$ height $\left(T_{11}\right)$. These results are in accordance to the findings of Kumar and Ananda (2002) who reported highest number of internodes through tongue grafting method in apple.

The effect of different top working treatments on total number of leaves per shoot was found to be statistically significant as shown in the Table 2. The maximum total number of leaves (59.59) were found in the plants top worked using tongue grafting at a height of $1.25 \mathrm{~m}$ $\left(\mathrm{T}_{2}\right)$, which was statistically at par with cleft grafting at $1 \mathrm{~m}$ height $\left(\mathrm{T}_{4}\right)$ and bark grafting at $1.25 \mathrm{~m}\left(\mathrm{~T}_{8}\right)$ with the number of leaves ranging 57.62 and 58.00, respectively. However, T-budding performed at $1 \mathrm{~m}$ height $\left(\mathrm{T}_{10}\right)$ resulted in least number of leaves (12.80), which was statistically at par with chip budding (14.07) at $1 \mathrm{~m}$ height $\left(\mathrm{T}_{11}\right)$. Zarad and Saleh (1994) recorded maximum number of leaves through tongue grafting in avocado. However, these results are contrary to the results obtainted by Safia et al., (2011) who found maximum number of leaves in plants propagated by cleft grafting method in pecan.

It is inferred from the data that there was no significant effect of different grafting/budding treatments on leaf area.

Maximum leaf chlorophyll content (2.89 $\mathrm{mg} / 100 \mathrm{~g}$ ) (Table 2) was found in the plants top worked by using tongue grafting at $1.25 \mathrm{~m}$ height $\left(\mathrm{T}_{2}\right)$, which was statistically at par with cleft grafting $(2.71 \mathrm{mg} / \mathrm{g})$ at $1 \mathrm{~m}$ height $\left(\mathrm{T}_{4}\right)$. While, the minimum leaf chlorophyll content $(2.02 \mathrm{mg} / \mathrm{g})$ was recorded in T-budding at $1 \mathrm{~m}$ height $\left(\mathrm{T}_{10}\right)$, which was statistically at par with tongue grafting $(2.08 \mathrm{mg} / 1 \mathrm{~g})$ at $1.5 \mathrm{~m}$ height $\left(\mathrm{T}_{3}\right)$. Carmen et al., (2009) reported that grafting improved net photosynthetic rate which resulted in assimilate accumulation and thus, enhanced the growth potential in stems and leaves. He further observed that grafting also improved stomatal conductance and intercellular $\mathrm{CO}_{2}$ concentration which strengthened the transfer capability of photosynthates and supply capability of photosynthetic materials to ensure increased photosynthetic efficiency and thus resulted in higher chlorophyll content in citrus.

Various top working treatments had no significant influence on diameter of grafted branches $(<4 \mathrm{~mm})$. The maximum diameter $7.75 \mathrm{~mm}$ of standard graftable shoots (4$8 \mathrm{~mm}$ ) was observed in the treatment tongue grafting at $1.25 \mathrm{~m}$ height $\left(\mathrm{T}_{2}\right)$, which was statistically at par with tongue grafting at $1 \mathrm{~m}$ height $\left(\mathrm{T}_{1}\right)$, cleft grafting at $1 \mathrm{~m}$ height $\left(\mathrm{T}_{4}\right)$ and bark grafting at $1.25 \mathrm{~m}$ height $\left(\mathrm{T}_{8}\right)$ with the diameter of $7.00 \mathrm{~mm}, 7.37 \mathrm{~mm}$ and 7.70 $\mathrm{mm}$, respectively. Whereas, T-budding at $1 \mathrm{~m}$ 
height $\left(\mathrm{T}_{10}\right)$ recorded lowest $(5.31 \mathrm{~mm})$ diameter and was found to be at par with tongue grafting $(6.18 \mathrm{~mm})$ at $1.5 \mathrm{~m}$ height $\left(\mathrm{T}_{3}\right)$, cleft grafting $(6.07 \mathrm{~mm})$ at $1.5 \mathrm{~m}$ height $\left(\mathrm{T}_{6}\right)$ and chip budding $(6.00 \mathrm{~mm})$ at $1 \mathrm{~m}$ height $\left(T_{11}\right)$. The higher branch diameter in tongue grafting may be attributed to greater nutrient uptake that showed faster (Skene et al., 1983) and uniform growth (Howard et al., 1974) as a result of quicker and stronger union formation and longer growing period. These results are also in accordance with Kim et al., (1989) and Zenginbal et al., (2006) who reported maximum scion diameter through tongue grafting.

Table.1 Effect of top working techniques on graft/bud take success and growth parameters in apple

\begin{tabular}{|c|c|c|c|c|c|c|c|c|}
\hline Treatments & $\begin{array}{c}\text { Graft/bu } \\
\text { d take } \\
\text { success } \\
(\%)\end{array}$ & $\begin{array}{c}\text { Total } \\
\text { number } \\
\text { of shoots }\end{array}$ & $\begin{array}{l}\text { Number } \\
\text { of } \\
\text { secondary } \\
\text { shoots }\end{array}$ & $\begin{array}{l}\text { Annual } \\
\text { primary } \\
\text { shoot } \\
\text { extension } \\
\text { growth } \\
\text { (cm) }\end{array}$ & $\begin{array}{l}\text { Annual } \\
\text { secondary } \\
\text { shoot } \\
\text { extension } \\
\text { growth } \\
\text { (cm) }\end{array}$ & $\begin{array}{l}\text { Average } \\
\text { annual } \\
\text { shoot } \\
\text { extension } \\
\text { growth } \\
\text { (cm) }\end{array}$ & $\begin{array}{l}\text { Number } \\
\text { of buds }\end{array}$ & $\begin{array}{l}\text { Number of } \\
\text { internodes }\end{array}$ \\
\hline $\mathbf{T}_{1}$ & $\begin{array}{c}80.75 \\
(63.99)^{*}\end{array}$ & 41.33 & 22.00 & 175.81 & 107.23 & 141.52 & 56.70 & 55.22 \\
\hline $\mathbf{T}_{2}$ & $\begin{array}{c}93.27 \\
(77.73)\end{array}$ & 49.67 & 30.67 & 182.00 & 112.00 & 147.00 & 57.80 & 56.80 \\
\hline $\mathbf{T}_{3}$ & $\begin{array}{c}80.55 \\
(63.87)\end{array}$ & 34.33 & 22.00 & 150.02 & 102.60 & 121.31 & 50.00 & 49.00 \\
\hline $\mathbf{T}_{4}$ & $\begin{array}{c}86.75 \\
(68.68) \\
\end{array}$ & 39.33 & 23.00 & 158.70 & 108.80 & 133.75 & 54.71 & 53.25 \\
\hline$T_{5}$ & $\begin{array}{c}75.48 \\
(60.37)\end{array}$ & 37.67 & 21.33 & 153.27 & 99.33 & 126.30 & 52.53 & 51.53 \\
\hline$T_{6}$ & $\begin{array}{c}78.24 \\
(62.20)\end{array}$ & 36.67 & 20.33 & 147.03 & 96.85 & 121.94 & 50.69 & 49.29 \\
\hline$T_{7}$ & $\begin{array}{c}77.02 \\
(61.47)\end{array}$ & 38.00 & 22.33 & 156.43 & 101.60 & 129.02 & 54.64 & 51.64 \\
\hline $\mathbf{T}_{8}$ & $\begin{array}{c}88.57 \\
(70.31)\end{array}$ & 43.67 & 25.00 & 177.28 & 109.27 & 143.27 & 57.40 & 52.85 \\
\hline $\mathbf{T}_{9}$ & $\begin{array}{c}69.37 \\
(56.41)\end{array}$ & 37.33 & 22.00 & 148.80 & 96.13 & 123.57 & 52.10 & 48.83 \\
\hline$T_{10}$ & $\begin{array}{c}78.30 \\
(62.25)\end{array}$ & 13.33 & 0.00 & 22.46 & 0.00 & 22.46 & 11.06 & 10.06 \\
\hline$T_{11}$ & $\begin{array}{c}85.82 \\
(68.18)\end{array}$ & 16.00 & 0.00 & 26.01 & 0.00 & 26.01 & 12.56 & 11.56 \\
\hline $\mathrm{CD}_{(0.05)}$ & 6.96 & 3.91 & 2.03 & 5.54 & 4.62 & 5.68 & 4.41 & 4.20 \\
\hline
\end{tabular}

*Figures in the parentheses are angular transformed values 
Table.2 Effect of top working techniques on leaf number, leaf area, chlorophyll content, shoot diameter, shoot proportion and production of per cent graftable scion wood in apple

\begin{tabular}{|c|c|c|c|c|c|c|c|c|c|c|}
\hline \multirow{2}{*}{$\begin{array}{c}\text { Treatment } \\
\text { s }\end{array}$} & \multirow{2}{*}{$\begin{array}{l}\text { Number } \\
\text { of leaves }\end{array}$} & \multirow{2}{*}{$\begin{array}{l}\text { Leaf } \\
\text { area } \\
\left(\mathrm{cm}^{2}\right)\end{array}$} & \multirow{2}{*}{$\begin{array}{c}\text { Chlorophyll } \\
\text { content } \\
\text { (mg/g fresh } \\
\text { weight) }\end{array}$} & \multicolumn{3}{|c|}{ Diameter of shoots } & \multicolumn{3}{|c|}{ Proportion of shoots } & \multirow{2}{*}{$\begin{array}{c}\text { Graftable } \\
\text { Scion } \\
\operatorname{wood}(\%)\end{array}$} \\
\hline & & & & $\begin{array}{c}<4 \\
\mathrm{~mm}\end{array}$ & $\begin{array}{l}4-8 \\
\mathrm{~mm}\end{array}$ & $\begin{array}{c}>8 \\
\mathrm{~mm}\end{array}$ & $\begin{array}{l}<4 \\
\mathrm{~mm}\end{array}$ & $\begin{array}{l}\text { 4-8 } \\
\mathrm{mm}\end{array}$ & $>8 \mathrm{~mm}$ & \\
\hline $\mathbf{T}_{1}$ & 57.03 & 32.04 & 2.16 & 3.55 & 7.00 & 14.39 & 89.33 & 213.67 & 114.67 & $\begin{array}{c}51.14 \\
(45.65)^{*}\end{array}$ \\
\hline $\mathbf{T}_{2}$ & 59.59 & 34.84 & 2.89 & 3.81 & 7.75 & 16.52 & 99.33 & 248.00 & 123.00 & $\begin{array}{c}52.73 \\
(46.57)\end{array}$ \\
\hline $\mathbf{T}_{3}$ & 51.18 & 29.78 & 2.08 & 3.28 & 6.18 & 13.31 & 75.00 & 182.67 & 105.00 & $\begin{array}{c}50.37 \\
(45.22)\end{array}$ \\
\hline $\mathbf{T}_{4}$ & 57.62 & 31.32 & 2.71 & 3.22 & 7.37 & 17.35 & 77.00 & 182.00 & 164.67 & $\begin{array}{c}42.96 \\
(40.95)\end{array}$ \\
\hline$T_{5}$ & 56.62 & 30.95 & 2.61 & 3.05 & 6.73 & 15.98 & 80.33 & 155.33 & 134.00 & $\begin{array}{c}42.01 \\
(40.40)\end{array}$ \\
\hline$T_{6}$ & 54.33 & 29.28 & 2.30 & 3.15 & 6.07 & 14.81 & 78.67 & 131.67 & 127.67 & $\begin{array}{c}38.94 \\
(38.61)\end{array}$ \\
\hline $\mathbf{T}_{7}$ & 55.61 & 30.87 & 2.43 & 3.23 & 7.13 & 14.47 & 75.67 & 147.33 & 139.33 & $\begin{array}{c}40.66 \\
(39.61)\end{array}$ \\
\hline$T_{8}$ & 58.00 & 32.80 & 2.87 & 3.66 & 7.70 & 16.68 & 90.00 & 190.00 & 154.00 & $\begin{array}{c}43.78 \\
(41.43)\end{array}$ \\
\hline $\mathbf{T}_{9}$ & 51.67 & 30.35 & 2.43 & 3.03 & 7.11 & 14.24 & 75.67 & 143.67 & 135.33 & $\begin{array}{c}40.50 \\
(39.52)\end{array}$ \\
\hline$T_{10}$ & 12.80 & 28.41 & 2.02 & 2.53 & 5.31 & 10.54 & 12.00 & 14.00 & 3.33 & $\begin{array}{c}47.93 \\
(43.81)\end{array}$ \\
\hline$T_{11}$ & 14.07 & 30.69 & 2.41 & 3.10 & 6.00 & 11.33 & 15.33 & 18.33 & 5.00 & $\begin{array}{c}47.29 \\
(43.44)\end{array}$ \\
\hline $\mathrm{CD}_{(0.05)}$ & 4.29 & NS & 0.40 & NS & 0.98 & 1.73 & 6.01 & 8.77 & 6.07 & 1.85 \\
\hline
\end{tabular}

*Figures in the parentheses are angular transformed values.

The maximum diameter of grafted branches (> $8 \mathrm{~mm}$ ) i.e. $17.35 \mathrm{~mm}$ was observed in the plants top worked with cleft grafting at $1 \mathrm{~m}$ height $\left(\mathrm{T}_{4}\right)$, which was statistically at par with tongue grafting $(16.52 \mathrm{~mm})$ at $1.25 \mathrm{~m}$ height $\left(\mathrm{T}_{2}\right)$, cleft grafting $(15.98 \mathrm{~mm})$ at $1.25 \mathrm{~m}$ height $\left(\mathrm{T}_{5}\right)$ and bark grafting $(16.68 \mathrm{~mm})$ at $1.25 \mathrm{~m}$ height $\left(\mathrm{T}_{8}\right)$. While, the minimum diameter of grafted branches (> $8 \mathrm{~mm}$ ) i.e. $10.54 \mathrm{~mm}$ was found in $\mathrm{T}$ - budding at $1 \mathrm{~m}$ height $\left(\mathrm{T}_{10}\right)$. From the study, it was observed that cleft grafting produced thicker shoots which might be due to the fact that branches used in cleft grafting are of greater diameter and also had more food reserves, which ultimately resulted in greater diameter of scion. These results are in conformity of Singh and Sharma (1979) who also recorded more scion diameter with increase in stock diameter in peach.

The number of thin shoots $(<4 \mathrm{~mm})$ were found significantly higher in the trees top worked with tongue grafting (99.33) at $1.25 \mathrm{~m}$ height $\left(T_{2}\right)$ while, the least number of shoots $(<4 \mathrm{~mm})$ were noticed in T-budding (12.00) at $1 \mathrm{~m}$ height $\left(\mathrm{T}_{10}\right)$ and was at statistically at par with chip budding (15.33) at $1 \mathrm{~m}$ height $\left(\mathrm{T}_{11}\right)$.

Maximum number of standard graftable shoots $(4-8 \mathrm{~mm})$ was obtained with tongue 
grafting (248.00) at $1.25 \mathrm{~m}$ height $\left(\mathrm{T}_{2}\right)$, which was significantly higher than all other treatments. Whereas, minimum number of graftable shoots (14.00) were recorded in the plants top worked with T-budding at $1 \mathrm{~m}$ height $\left(\mathrm{T}_{10}\right)$, which was statistically at par with chip budding (18.33) at $1 \mathrm{~m}$ height $\left(\mathrm{T}_{11}\right)$.

Highest number (164.67) of shoots with diameter $>8 \mathrm{~mm}$ were obtained in the plants top worked with cleft grafting at a height of 1 $\mathrm{m}\left(\mathrm{T}_{4}\right)$, which was superior than all other treatments. However, lowest number of shoots with daimeter thick $>8 \mathrm{~mm}$ were recorded in the treatment T-budding (3.33) at $1 \mathrm{~m}$ height $\left(\mathrm{T}_{10}\right)$, which was statistically at par with chip budding (5.00) at $1 \mathrm{~m}$ height $\left(\mathrm{T}_{11}\right)$.

Top working performed using tongue grafting at $1.25 \mathrm{~m}$ height $\left(\mathrm{T}_{2}\right)$ resulted in the maximum percentage of graftable scion wood $(52.73 \%)$, which was statistically at par with tongue grafting $(51.14 \%)$ at $1 \mathrm{~m}$ height $\left(\mathrm{T}_{1}\right)$ and tongue grafting $(50.37 \%)$ at $1.5 \mathrm{~m}$ height $\left(\mathrm{T}_{3}\right)$. However, the minimum graftable scion wood $(38.94 \%)$ were obtained in the plants top worked using cleft grafting at $1.5 \mathrm{~m}$ height $\left(\mathrm{T}_{6}\right)$ and was found to be statistically at par with cleft grafting (42.01) at $1.25 \mathrm{~m}$ height $\left(\mathrm{T}_{5}\right)$, bark grafting $(40.66 \%)$ at $1 \mathrm{~m}$ height $\left(\mathrm{T}_{7}\right)$ and bark grafting $(40.50 \%)$ at 1.5 $\mathrm{m}$ height $\left(\mathrm{T}_{9}\right)$. These results are in accordance with the findings of Godeanu et al., (2001) who reported a positive correlation between the number of scion wood and the length and diameter of the mother branch. Similar results were also obtained by Li et al., (1995) who also noticed increase in bud wood production due to a greater number of shoots and greater shoot length.

On the basis of the results obtained in the present study, it can be concluded that different top working treatments had significant effect on the bud wood production in apple. Among the different treatments, top working performed at a height of $1.25 \mathrm{~m}$ gave the best results in respect of graft/bud take success, total number of shoots, number of secondary shoots, number of standard graftable shoots, maximum pertcentage of graftable scion wood and graftable scion wood. Cleft grafting performed at a height of $1 \mathrm{~m}$ however, resulted in maximum diameter and number with $>8 \mathrm{~mm}$ shoots.

\section{Acknowledgements}

Authors are highly thankful to the facilities and funds provided by Dr. Yashwant Singh Parmar University of Horticulture and Forestry, Nauni, Solan 173230 (H.P.) India.

\section{References}

Abassi N, Hafiz IA, Qureshi AA, Ali I and Mahmood SR. 2014. Evaluating the success of vegetative propagation techniques in loquat (Eriobotrya japonica) cv. Mardan. Pakistan Journal of Botany 46: 579-584.

Akinnifesi FK, Sileshi G, Mkonda A, Ajayi OC, Mhango J and Chilanga T. 2008. Germplasm supply, propagation and nursery management of miombo fruit trees. World Agroforestry Centre: Nairobi. UK 10: 341-368.

Anonymous. 2018a. Horticulture Statistics at a Glance. http://www.nhb.gov.in.

Anonymous. 2018b. Horticultural Development in Himachal Pradesh at a Glance. http://hpagrisnet.gov.in.

Bhardwaj KN. 1983. Standardization of vegetative propagation techniques in pecan nut (Carya illionensis). Thesis Abstracts, Haryana Agricultural University 9: 65.

Bohra and Singh J. 2008. Performance of different grafting methods in peach cv. Sharbati under Tarai condition of Uttarakhand. M.Sc. Thesis. GB Pant University of Agriculture and Technology, Pantnagar263145 (Uttarakhand).

Carmen MG, Liosa MJ and Antonio Q. 2009. Rootstock effects on leaf photosynthesis in 
'Navelina' trees grown in calcareous soil. HortScience 44: 280-283.

Chadha KL and Awasthi RP. 2005. Apple: Improvement, Production and Post-harvest management. Malhotra publishing house, New Delhi. 1p.

Chadha KL. 2001. Apple In: Handbook of Horticulture. Council of Agriculture Research, New Delhi. 119p.

Chandel JS, Negi KS and Jindal KK. 1998. Studies on vegetative propagation in kiwi (Actinidia deliciosa Chev.). Indian Journal of Horticulture 55: 52-54.

Chauhan A, Dwivedi MP and Tomar CS. 2000. Effect of different methods and dates of grafting on per cent bud take and growth of apricot plant. Scientific Horticulture 9: 73-77. 333339

Daouda KK, Jane K, Lucien D, Jean-Luc K, Kouadio B and Christophe KE. 2018. Comparison of grafting techniques and their effects on some growth parameters of ten elite cocoa clones (Theobroma cacao L.). African Journal of Agricultural Research 13: 2249-2255.

Dwivedi SK, Singh B and Paljor E. 2000. Studies on vegetative propagation of apricot (Prunus armeniaca L.) through grafting in Ladakh. Indian Journal of Horticulture 57: 39-41.

Gautam DR and Kumar A. 2003. Studies on top working techniques in walnut (Juglans regia L.) trees. M.Sc. Thesis. Dr. Yashwant Singh Parmar University of Horticulture and Forestry, Solan.

Godeanu I, Cosmulescu S and Baciu A. 2001. Research concerning the influence of pruning applied to mature walnut trees for obtaining quality scion wood. Acta Horticulturae 544: 495-502.

Gomez KA and Gomez AA. 1984. Statistical procedures for agricultural research. John Wiley and Sons Inc, New York. 680p.

Hartmann HT, Kester DE, Davies FT and Geneve RL. 1997. Plant Propagation: Principles and Practices. $6^{\text {th }}$ ed. Prentice Hall of India Pvt. Ltd., New Delhi. 532p.

Hartmann HT, Kester DE, Davies FT and Geneve RL. 2007. Plant Propagation: Principles and Practices. $7^{\text {th }}$ ed. Prentice Hall of India Pvt. Ltd., New Delhi. pp. 199-248.
Hiscox JD and Israelstam GF. 1979. A method for extraction of chlorophyll from leaf tissues Masceration. Canadian Journal of Biology 57: 332-334.

Howard BH, Skene DS and Coles JS. 1974. The effect of different grafting methods upon the development of one-year old nursery apple trees. Journal of Horticultural Science and Biotechnology 49: 287-295.

Jindal KK, Kakara BK, Sharma VK and Uppal DK. 1992. Apples. In: Emerging trends in temperate fruits production in India (Chadda KC, Uppal DK, Pal RN, Awasthi RP and Ananda SA eds). NHB Ted Communication, Gurgaon, India. pp. 3994.

Karldag H and Estken A. 2012. Effects of grafting height of MM106 rootstock on growth, lateral shoot formation and yield in apple trees. Journal of Horticultural Science and Biotechnology 87: 409-412.

Kim YK, Park SA, Han MS and Yang LS. 1989. The effect of method and date of grafting on graft union development and scion growth in Fuji apple on Malussie boldii seedlings. Korean Society of Horticulture 7: 108-109.

Kumar R and Ananda SA. 1996. Effect of methods and heights of grafting on the growth and proportion of saleable plants in spur type apples. Progressive Horticulture 36: $12-15$.

Kumar R and Ananda SA. 2002. Effects of grafting method and height on the growth of grafted plants and production of feathers in spur type apple cultivars at nursery stage. Journal of Applied Horticulture 4: 54-55.

Li ZQ, Sun GM, Zhang GS, Yang SW and Lu YX. 1995. Study on the top working techniques for apple trees. China Fruits 4: 8-11.

Mannan MM, Islam MM and Khan SA. 2006. Effects of methods of grafting and age of rootstock on propagation of off-season germplasm of jackfruit (Artocarpus heterophyllus). Khulna University Studies 7: 77-82.

Mehta G, Kumar D, Bakshi P, Wali B, Jasrotia A, Bushan J and Bhat DJ. 2018. Standardization of method and time of 
grafting on pecan (Carya illinoensis) under intermediate agro-climatic conditions. Indian Journal of Agricultural Sciences 88: 104-107.

Mng'omba SA, Akinnifesi FK, Sileshi G and Ajayi OC. 2010. Rootstock growth and development for increased graft success of mango (Mangifera indica) in the nursery. African Journal of Biotechnology 9: 13171324.

Mukred A and Hrotkó K. 1989. A szemzési mód hatása az oltványnevelés kihozatali arányaira és az oltványok minóségére. Kertgazdaság 2: 13-19.

Plathia M, Sharma A, Wali VK, Shah RA and Gupta R. 2016. Standardization of method and time of grafting of peach (cv. Shan-EPunjab) on peach seedling rootstock. Green Farming 7: 1244-1247.

Rafikul I. 2013. Effect of scion diameter on grafting success, survivability and growth of different mango varieties. Mymensingh: Bangladesh Agricultural University.

Rezaee R and Vahdati K. 2008. Introducing a simple and effective procedure for top working Persian walnut tree. Journal American Pomological Society 62: 21-26.

Rongting X and Pinghai D. 1993. A study on the uniting process of walnut grafting and the factors affecting. Acta Horticulturae 311: 160-170.

Safia TA, El-Taweel AA and Ali AA. 2011. Studies on the vegetative propagation of pecan (Carya illinoinensis) grafting by cleft grafting method under open field conditions. Journal of Agricultural Research 37: 141-161.

Sharma HC and Singh R. 1979. Vegetative propagation of peach under subtropical conditions. Punjab Horticultural Journal
19: $53-55$

Sharma RC and Dhillon BS. 1981. Grafting peach in October. Indian Horticulture 26: 26-27.

Singh PN and Sharma R. 2017. Relative performance of chip and T-budding over tongue grafting in peach (Prunus persica (L.) Batsch) cv. Shan-e-Punjab. M.Sc. Thesis. G.B. Pant University of Agriculture and Technology, Pantnagar 263145 (Uttarakhand) India.

Skene DS, Shepherd HR and Howard BH. 1983. Characteristic anatomy of union formation in T-and chip-budded fruit and ornamental trees. Journal of Horticultural Science 58: 295-299.

Srivastava KK, Sharma AK, Sharma MK and Khalil A. 2007. Standardization of budding time and methods in pecan. Haryana Journal of Horticultural Sciences 36: 55-56.

Tchoundjeu Z, Tsobeng AC, Asaah E and Anegbeh P. 2010. Domestication of Irvingia gabonensis (Aubry Lecomte) by air layering. Journal of Horticulture and Forestry 2: 171-179.

Vahdati K. 2000. Walnut situation in Iran. Nusis Newsletter 9: 32-33.

Zarad SS and Saleh MA. 1994. Evaluation of four grafting methods and two application dates for three avocado cultivars. Annals of Agricultural Science, Ain Shams University 6: 67-69.

Zenginbal H, Ozcan M and Demir T. 2006. An investigation on the propagation of kiwifruit (Actinidia deliciosa A. Chev.) by grafting under Turkey ecological conditions. International Journal of Agricultural Research 1: 597-6

\section{How to cite this article:}

Ankita Dhiman, D.D. Sharma, D.P. Sharma and Gopal Singh. 2020. Comparative Studies on Top Working Techniques for Bud Wood Production in Apple (Malus $\times$ Domestica Borkh.). Int.J.Curr.Microbiol.App.Sci. 9(11): 221-230. doi: https://doi.org/10.20546/ijcmas.2020.911.026 